\title{
Gas chromatographic and antimicrobial analyses of phenolic compounds in Senna alata (L.) Roxb. (Fabales: Fabaceae)
}

\section{Funmilayo Adelowo, Oluwole Oladeji*}

Department of Pure and Applied Chemistry. Ladoke Akintola University of Technology. P. M. B. 4000. Ogbomoso. Nigeria.*Email: oladeji_oluwole@yahoo.com.

\begin{abstract}
This present work is aimed at determining the chemical components in Senna alata (L.) Roxb. (Fabales: Fabaceae), that contains a large array of phenolic compounds which make it useful as antifungal and antibacterial. Despite a notable success in the recent researches, yet, the quantification of the chemical components has not been actually specified. There is a claim by local people that $S$. alata can cure fungi and bacteria related diseases. Therefore, there is a need to ascertain this claim by examining the bioactive components present in the plant. The Gas Chromatography (GC) analysis was performed using a Clarus 500 Perkin Elmer gas chromatography equipped with an Elite-5 capillary column with the addition of an absolute alcohol. The antimicrobial analysis was carried out using Agar Disc Diffusion Method. In the GC chromatogram, four prominent peaks were observed in leaf chromatogram, three peaks in flower chromatogram and five peaks in fruit chromatogram, respectively. The flower contained the highest amount of cinnamic acid (52.91\%) and the fruit contained the least (17.03\%). The presence of some bioactive metabolites could be responsible for the observed antifungal and antibacterial activities on the susceptible organisms studied. It could be concluded that this plant is natural sources of antimicrobial substances of high importance and are useful in chemotherapy.
\end{abstract}

Keywords: Bioactive component; Chromatograph; Chemotherapy; Phenolic compounds.

Resumo. Análises cromatográfica gasosa e antimicrobiana de compostos fenólicos em Senna alata (L.) Roxb. (Fabales: Fabaceae). O presente trabalho tem como objetivo determinar os componentes químicos em Senna alata (L.) Roxb. (Fabales: Fabaceae) que contém uma grande variedade de compostos fenólicos que a tornam útil como antifúngica e antibacteriana. Apesar do sucesso notável nas pesquisas recentes, contudo, a quantificação dos componentes químicos não foi realmente especificada. Há uma reivindicação por povos locais que a $S$. alata pode curar fungos e doenças relacionadas às bactérias. Portanto, há uma necessidade de verificar esta afirmação examinando os componentes bioativos presentes na planta. A análise cromatográfica gasosa (CG) foi realizada utilizando uma cromatografia de gases Clarus 500 Perkin Elmer equipada com uma coluna capilar Elite- 5 com a adição de álcool absoluto. A análise antimicrobiana foi realizada utilizando o método disco-difusão. No cromatograma de CG, foram observados quatro picos proeminentes no cromatograma de folhas, três picos no
Recebido:

25/10/2016

Aceito:

29/11/2016

Publicado:

$31 / 12 / 2016$

Acesso Aberto Artigo completo

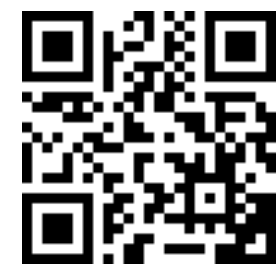

ORCIID

(D) 0000-0002-1949-2418 Funmilayo Adelowo (D) $0000-0003-3355-2488$ Oluwole Oladeji 
cromatograma de flor e cinco picos no cromatograma de fruto, respectivamente. A flor continha a maior quantidade de ácido cinâmico (52,91\%) e o fruto continha o mínimo (17,03\%). A presença de alguns metabólitos bioativos poderia ser responsável pelas atividades antifúngica e antibacteriana observadas nos organismos susceptíveis estudados. Pode-se concluir que esta planta é fonte natural de substâncias antimicrobianas de alta importância e são úteis em quimioterapia.

Palavras-chave: Componentes bioativos; Cromatografia; Quimioterapia; Compostos fenólicos.

\section{Introduction}

Senna alata (L.) Roxb. (Fabales: Fabaceae) (previously named Cassia alata) is a medicinal plant of Fabaceae Family. It has many common names such as candle bush, acapulo, ringworm bush and calabra bush. It is a shrub with usually an average height of between 1 and $5 \mathrm{~m}$ and has horizontally spread branches. Its leaves are par pinnate of between 30 to $60 \mathrm{~cm}$ long and consisting of 8 to 20 pairs of leaflets (Farnsworth and Bunyapraphatsara, 1992).

S. alata are able to synthesize a multitude of organic molecules or phytochemicals, referred to as "secondary metabolites" such as phenolic compounds (Shahidi et al., 2004). Phenolic compounds are plant secondary metabolites that constitute one of the most common and widespread groups of substances in plants. The term "phenolics" or "polyphenols" are defined as substances that possess an aromatic ring having one or more hydroxyl substituent and functional derivatives such as esters, methyl ethers, glycosides, etc (Kliebenstein, 2004). Each class of phenolic compounds has distinctive absorption characteristics which make them act as good antimicrobial agents among many other health benefits (Makinde et al., 2007). Several classes of phenolics have been categorized on the basis of their basic skeleton; simple phenol (benzoquinones, phenolic acid, hydroxycinnamic acids, coumarins, phenylpropanes) (Whiting, 2001) and complex phenols (flavonoids, tannins, lignins) (Osbourn et al., 2003). Phenolic compounds are widespread in the plant kingdom; serve specific functions in antimicrobial activities, flower pigmentation, UV-protection, plant defense against pathogens and legume nodulations (Wagner et al., 2002).

GC is one of the most widely used analytical techniques (Scot, 1998). They have some characteristics such as small samples ( $\mu$ l or $\mu$ g needed), high resolution, reliable, relatively simple and cheap, nondestructive, sensitive detectors (easy ppm, often ppb) and highly accurate quantification (1-5\% RSD. With the commercial introduction of gas chromatography (GC) 50 years ago, it has been used to help determine food composition and discover our nutritional needs. Furthermore, GC has been considered to be the only adequate approach to measure many of the organic contaminants that occur at trace concentrations in complex food and environmental sample (Jennings et al., 1997). It has also been a major instrument in helping humans realize that we must use caution with agricultural and industrial chemicals to avoid harming our health, the food supply, and the ecosystem that we rely upon for sustainability. The scientific discoveries made with the help of GC in agricultural and food sciences have contributed to more plentiful and healthier food, longer and better lives, and an expanding population of 6 billion people. The applications of GC in qualitative and quantitative analysis have contributed a lot in analytical chemistry of food analysis (McGorrin and Meyers, 2000), and particularly food applications involving GC, such as carbohydrates and amino acids, lipids and accompanying lipophilic compounds, aroma and flavors, and pesticide residues (Careri and Mangia, 
2001). In the field of plant chemistry, GC is sometimes incorporated with mass spectrometer in analyzing organic compounds present in plants, the peak area and retention in the chromatogram are important to quantify and qualitate these compounds.

The use of herbal medicine for the treatment of bacteria and fungi that caused related diseases gave rise to the introduction of antibiotics or natural drugs (Akinyemi et al., 2000). Plants (S. alata) are an important source of medicines and play a key role in world health. Almost all cultures from ancient times to today have used plants as medicine. Medicinal plants are important to the global economy, approximately $85 \%$ of traditional medicine preparations or drugs involve the use of plants or plant extracts (Vieira and Skorupa, 1993). The growing rate of the activities of microbes increases every day. Virtually everything that surrounds man are contaminated and polluted with these microbes (Beisaga et al., 2011). In recent times, people depend on medicinal plants without the knowledge on the chemical composition of the plant. In some countries, National Health Surveillance Agency (ANVISA) has canceled the registration of these products, and their use was discontinued because of a lack of studies to characterize and analyze the plant raw material and ensure the effectiveness and safety of its use. Therefore, in the attempt to analyse the phenolic compounds present in Senna alata, gas and thin-layer chromatographic analyses were used and are tested on some selected isolates to determine their antimicrobial activities.

\section{Materials and Methods}

\section{Chemicals}

Chemical were from sigma unless otherwise stated. All chemicals and solvents used were of analytical grade. Gallic acid and quercetin were recrystallized while the methanol and ethanol purified by distillation and the fraction collected at $58-75^{\circ} \mathrm{C}$.

\section{Collection of sample}

The samples (S. alata) were collected in a farm in Odokoto Area, Ogbomoso, Nigeria, between May and August, 2015 and identified by the herbarium unit of the Department of Pure and Applied Biology, Lautech, Ogbomoso. The leaves, fruit and the flower samples of S. alata were collected separately and put in different polythene bags. The samples were spread on a flat surface and air-dried for 25 days.

\section{Sample preparation}

The dried samples (fruit, leaf and flower) were pulverized and sieved using a sieve of mesh size of $20 \mathrm{~mm}$. The sieved samples were stored in air-tight containers and put in a refrigerator at $4{ }^{\circ} \mathrm{C}$ for further analysis.

\section{Extraction}

Soxhlet apparatus was used for the extraction and was carried out based on the method of Adelowo and Oladeji (2016). The pulverized samples were weighed. $15 \mathrm{~g}$ each of the leaves, flowers and fruits samples were weighed separately. They were then kept in different extraction thimble. $200 \mathrm{~mL}$ of ethanol and methanol were used for the extraction. The refluxing was carried out for 6 hours. The extracts were obtained in the quick-fit flask.

\section{Concentration}

The extracts were concentrated using a Rotary Evaporator. The six concentrated extracts obtained (ethanolic extracts of leaves, flowers and fruits) also; the (methanolic extracts of leaves, flowers and fruits) were kept in screw cap sample bottles.

\section{Column packing and developing the chromatogram \\ The column used was made of} Pyrex glass, and have small diameter so as to have effective separation and obtain distinctive bands. The cleanup method was carried out according to the method of Adelowo and Oladeji (2016). 


\section{Thin-layer chromatography analysis of phenolic compounds \\ Thin-layer chromatography was} performed using pre-coated silica plate according to the method of Usha (2011). These plates used were pre-coated with silica gel GF254 (Merck $20 \times 20 \mathrm{~cm}$ ). The solvent system used was petroleum ether: ethanol: acetone $(5: 3: 1$, vol: $18 \mathrm{~mL})$ as the mobile phase. The solutions of the standard at $5 \mathrm{ppm}$ were prepared by dissolving 0.01 $\mu \mathrm{g}$ of each standard (gallic acid and quercetin for phenolics and flavonoid, respectively) in $20 \mathrm{~mL}$ of DMSO. The plates were then dipped in a chamber that has been saturated with iodine vapour for identification of the spots. After 3-5 min, the plate was removed and the spot detected were circled and the retardation factors were calculated. This analysis was used for the other fractions obtained from the other extracts.

\section{phenolic compounds}

Gas chromatographic analysis of

The GC analysis was performed using a Clarus 500 Perkin Elmer gas chromatography equipped with an Elite-5 capillary column with the addition of an absolute alcohol.

\section{experiments}

\section{Antimicrobial}

\section{screening}

The fractions obtained were screened for their fungitoxicity and bacteriocity "Inhibition of growth method".

\footnotetext{
Preparation of fungus culture in Potato Dextrose Agar (PDA) and bacteria culture in Nutrient Agar (NA). About $10 \mathrm{~mL}$ of Potato Dextrose Agar (PDA) was dispensed into each of the four test tubes and sterilized in the autoclave at $121{ }^{\circ} \mathrm{C}$ for $15 \mathrm{~min}$. Each sterilized test tubes of PDA was inoculated with one of the fungi species: Aspergillus niger and Candida albicans. Also, $10 \mathrm{~mL}$ of Nutrient Agar (NA) was dispensed into each of the six test tubes and sterilized in the autoclave at $121{ }^{\circ} \mathrm{C}$ for $15 \mathrm{~min}$. Each sterilized test tubes of NA was inoculated with one of the bacteria species Bacillus cereus, Staphylococcus aureus and Klebsiella spp.
}

The isolates were identified at the microbiological laboratory of the Department of Pure and Applied Biology, Lautech, Ogbomosho, Oyo State, Nigeria.

\section{Preparation of concentration of standard and the sample \\ The solutions of extracts and the} standard (methanol and ethanol) at $5 \mathrm{ppm}$ were prepared by dissolving $0.1 \mu \mathrm{g}$ of each extracts in $20 \mathrm{~mL}$ of DMSO. Other concentrations (25 ppm, $50 \mathrm{ppm}, 100 \mathrm{ppm}$, $150 \mathrm{ppm}$, and $250 \mathrm{ppm}$ ) of the extracts were got by serial dilution of the stock solution (i.e. 5 ppm solution). Methanol and ethanol served as the control.

\section{Antifungal screening of the phenolic compounds \\ Potato Dextrose Agar was} inoculated with the spore suspension of each fungus. About $6 \mathrm{~mm}$ diameters filter paper discs and were sterilized in the oven at $160{ }^{\circ} \mathrm{C}$ for $2 \mathrm{~h}$. With the aid of sterilized pair of forceps, filter paper discs that have been soaked in solution of various concentrations of each extracts and standard were put on the surface of inoculated PDA plates. Filter papers discs were also soaked in the control and placed on the surface of each inoculated PDA plate. All the PDA plates were put in an incubator at room temperature. The growth diameter of the fungal spores was measured after incubating at $30^{\circ} \mathrm{C}$ for 3 days.

\section{Antibacterial screening of the phenolic compounds}

Nutrient Agar was inoculated with the spore suspension of each bacterium. Each inoculated PDA plate was then properly drained. About $6 \mathrm{~mm}$ diameter filter paper discs were sterilized in the oven at $160{ }^{\circ} \mathrm{C}$ for $2 \mathrm{~h}$. With the aid of sterilized pair of forceps, filter paper discs that have been soaked in solution of various concentrations of each extracts and standard were put on the surface of inoculated NA plates. The growth diameter of the bacterial spores was measured after incubating at $37^{\circ} \mathrm{C}$ for $24 \mathrm{~h}$. The minimum concentration of each extract that inhibits the growth of 
the bacterium was taken as the 'Minimum Inhibitory Concentration’ (MIC).

\section{Results and discussion}

\section{Thin-layer chromatographic analysis of phenolic compounds}

The fractions of $S$. alata obtained were analyzed on a pre-coated silica gel plate in order to identify the compounds present in each of the fractions obtained from the extracts. The retention factor values were obtained after the development of the chromatogram of sample components. The $\mathrm{R}_{f}$ values for the fractions were then compared with that of standard after detection of the spots in iodine chamber. The compound obtained was suggested to be a flavonoid as the detected spot(s) exhibited light yellow appearance on silica gel plate.
The Thin-layer chromatography results for both the samples and standards used are shown in Table 1 showed that different phenolic compounds, flavonoids and phenolic acids were present in the investigated fractions. The result of the triplicate analysis of the retardation factor is given in Table 1 . The mean retardation values of the $S$. alata samples when compared to the retardation values of gallic acid and quercetrin showed that the fractions contained a chemical component in the class of gallic acid and quercetrin respectively. A largest number of flavonoids (quercetin and some unidentified flavonoid-glycosides) and phenolic acids (gallic acid, chlorogenic, caffeic, coumaric and vanillic acid) were found in methanol and ethanol fractions. Rutin and some unidentified flavonoid-glycosides are present in the ethanol and methanol fractions.

Table 1. The $\mathrm{R}_{f}$ values and mean $\mathrm{R}_{f}$ values of the $S$. alata extracts and standard spotted.

\begin{tabular}{lcccc}
\hline Sample spotted & $\begin{array}{c}\mathbf{R}_{\boldsymbol{f}} \text { values } \\
\text { (Gallic acid) }\end{array}$ & $\begin{array}{c}\text { Mean } \mathbf{R}_{\boldsymbol{f}} \\
\text { values } \\
\text { (Gallic acid) }\end{array}$ & $\begin{array}{c}\mathbf{R}_{\boldsymbol{f}} \text { values } \\
\text { (Quercetin) }\end{array}$ & $\begin{array}{c}\text { Mean } \mathbf{R}_{\boldsymbol{f}} \text { values } \\
\text { (Quercetin) }\end{array}$ \\
\hline Methanolic Flower & $0.42,0.43,0.45$ & 0.43 & $0.68,0.71,0.74$ & 0.71 \\
Methanolic Fruit & $0.37,0.39,0.43$ & 0.40 & $0.64,0.67,0.72$ & 0.68 \\
Methanolic Leaf & $0.36,0.42,0.44$ & 0.41 & $0.64,0.72,0.75$ & 0.70 \\
Ethanolic Flower & $0.39,0.44,0.47$ & 0.43 & $0.66,0.71,0.73$ & 0.70 \\
Ethanolic Fruit & $0.33,0.41,0.44$ & 0.39 & $0.61,0.66,0.75$ & 0.67 \\
Ethanolic Leaf & $0.36,0.39,0.44$ & 0.40 & $0.64,0.69,0.74$ & 0.69 \\
\hline
\end{tabular}

The results of the thin-layer chromatography analyses showed that different flavonoids and phenolic acids were present in the investigated fractions, this agree with Sermakkani et al. (2009) that discovered that there are numbers of flavonoids (rutin, quercetin and some unidentified flavonoid glycosides) and phenolics (chlorogenic, caffeic, coumaric and vanillic acid) in both the ethanolic and methanolic extract of $S$. alata. gel plate. The results of the $\mathrm{R} f$ values agree with that of Rahaman et al. (2006) in which after the determination of the light yellow spots, they sprayed with ceric sulphate reagent to obtain a deep yellow colour which indicate the presence of flavonoid. Also, it agrees with the result of Owoyale et al. (2005). They discovered that the ethanol and methanol fractions also contain coumaric, caffeic and chlorogenic acid.

\section{Gas chromatogram}

The eluent obtained from column purification of $S$. alata leaf showed four peaks in the chromatogram (Figure 1). These peaks indicated the presence of four major compounds in the extract. The nomenclature, molecular formula, molecular weight, retention time and the 
percentage peak area of these compounds are shown in Table 2. The chemical constituents comprised of 3,5-Diethyl-2-n- propylpyridine (18.04\%), cinnamic acid (46.37\%), hexadecanoic acid (16.06\%) and Rhodopin (19.52\%).

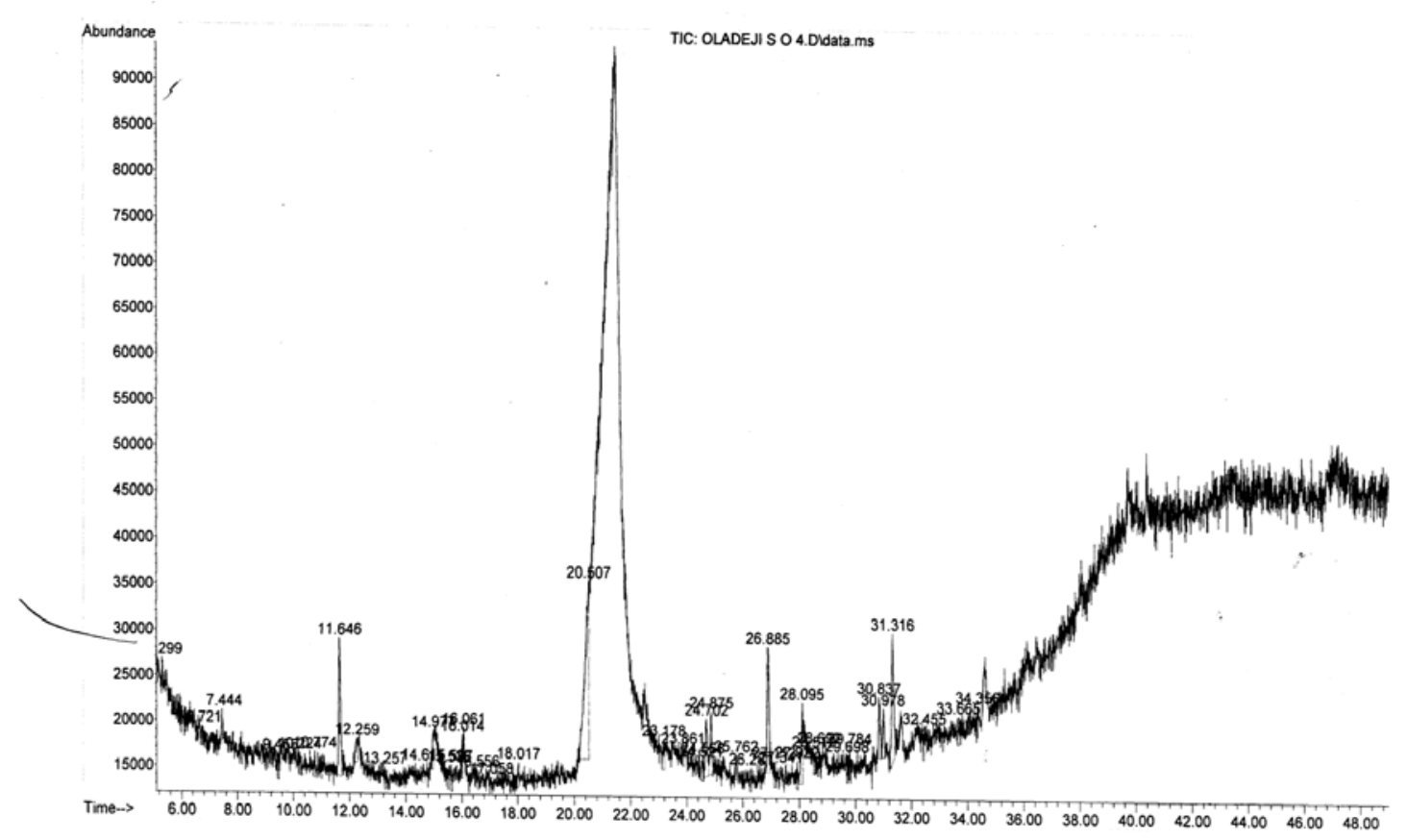

Figure 1. Gas chromatogram of Senna alata leaf.

Table 2. Phenolic compounds identified from the GC analysis of the fraction eluted from fruit extract.

\begin{tabular}{|c|c|c|c|c|c|}
\hline $\begin{array}{c}\text { Chromatographic } \\
\text { peak }\end{array}$ & Compound name & & $\begin{array}{c}\text { Molecular } \\
\text { weight }\end{array}$ & $\begin{array}{c}\text { Retention } \\
\text { time }\end{array}$ & $\begin{array}{c}\text { Peak area } \\
(\%)\end{array}$ \\
\hline 1 & 3,5-Diethyl-2-n-propylpyridine & & 121 & 11.636 & 29.09 \\
\hline 2 & Methaqualone & & 250 & 18.221 & 4.04 \\
\hline 3 & Hexadecanoic acid & & 256 & 26.885 & 24.45 \\
\hline 4 & $\begin{array}{l}\text { 1-Phenyl-3- } \quad \text { (4-methoxyphenyl) } \\
\text { pyrazoline }\end{array}$ & $-2-$ & 174 & 30.852 & 25.38 \\
\hline 5 & Cinnamic acid & & 250 & 30.986 & 17.03 \\
\hline
\end{tabular}

The eluent obtained from column purification of $S$. alata flower showed three peaks from the chromatogram (Figure 2). These peaks indicated the presence of three major phenolic compounds in the extract. The nomenclature, molecular formula, molecular weight, retention time and the percentage peak area of these compounds were shown in Table 2 . The chemical constituents comprise cinnamic acid
(52.91\%), 2-Thiazolamine (13.70\%) and Hexadecanoic acid (33.40\%).

The eluent obtained from the column purification methanolic extract of $S$. alata fruit showed five peaks in the chromatogram (Figura 3). These peaks indicated the presence of five major compounds in the extract. The nomenclature, molecular formula, molecular weight, retention time and the 
percentage peak area of these compounds are shown in Table 2. The chemical constituents 3,5-diethyl-2-n-propylpyridine (29.09\%), methaqualone (4.04\%), hexadecanoic acid (24.45\%), 1-phenyl-3-

(4-methoxyphenyl)-2-pyrazoline (25.38\%) and cinnamic acid (17.03\%).

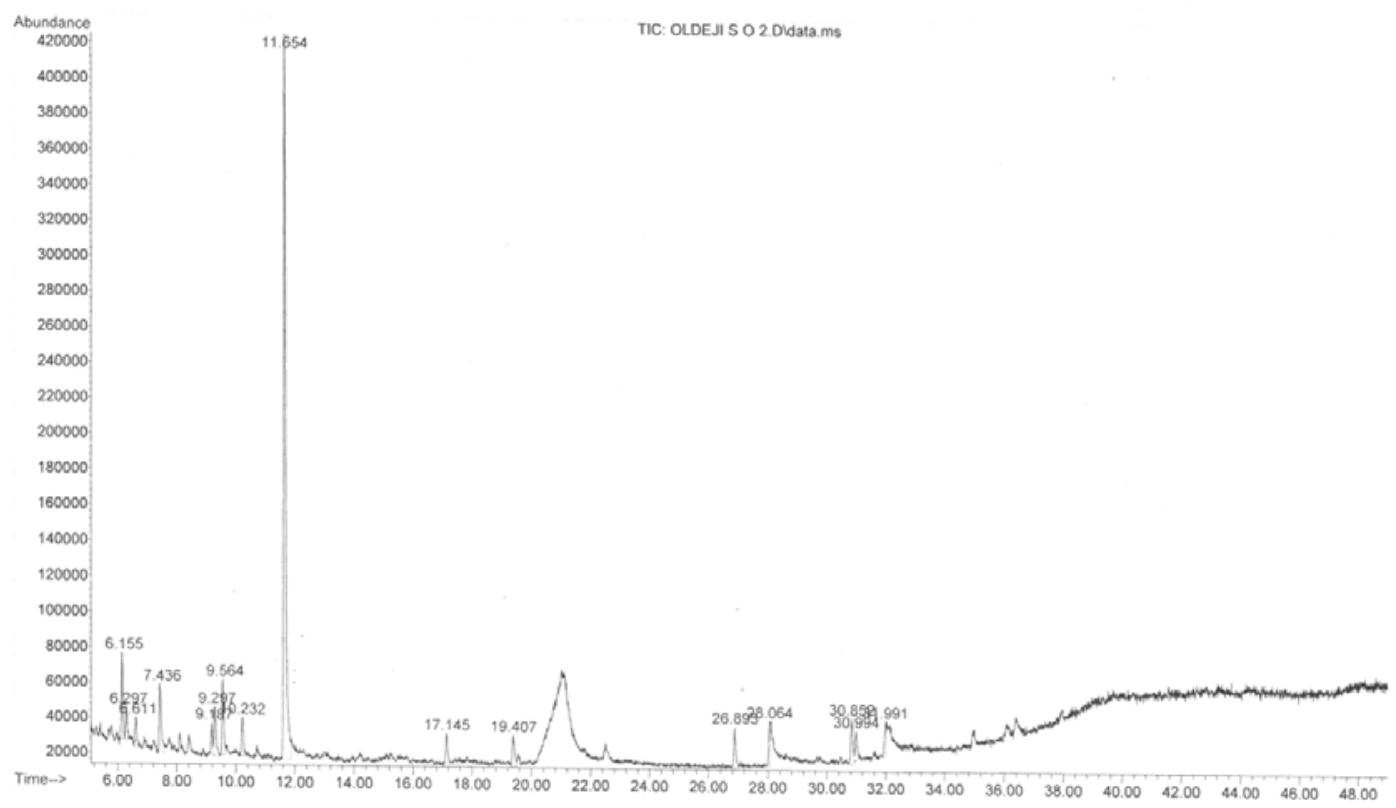

Figure 2. Gas chromatogram of Senna alata flower.

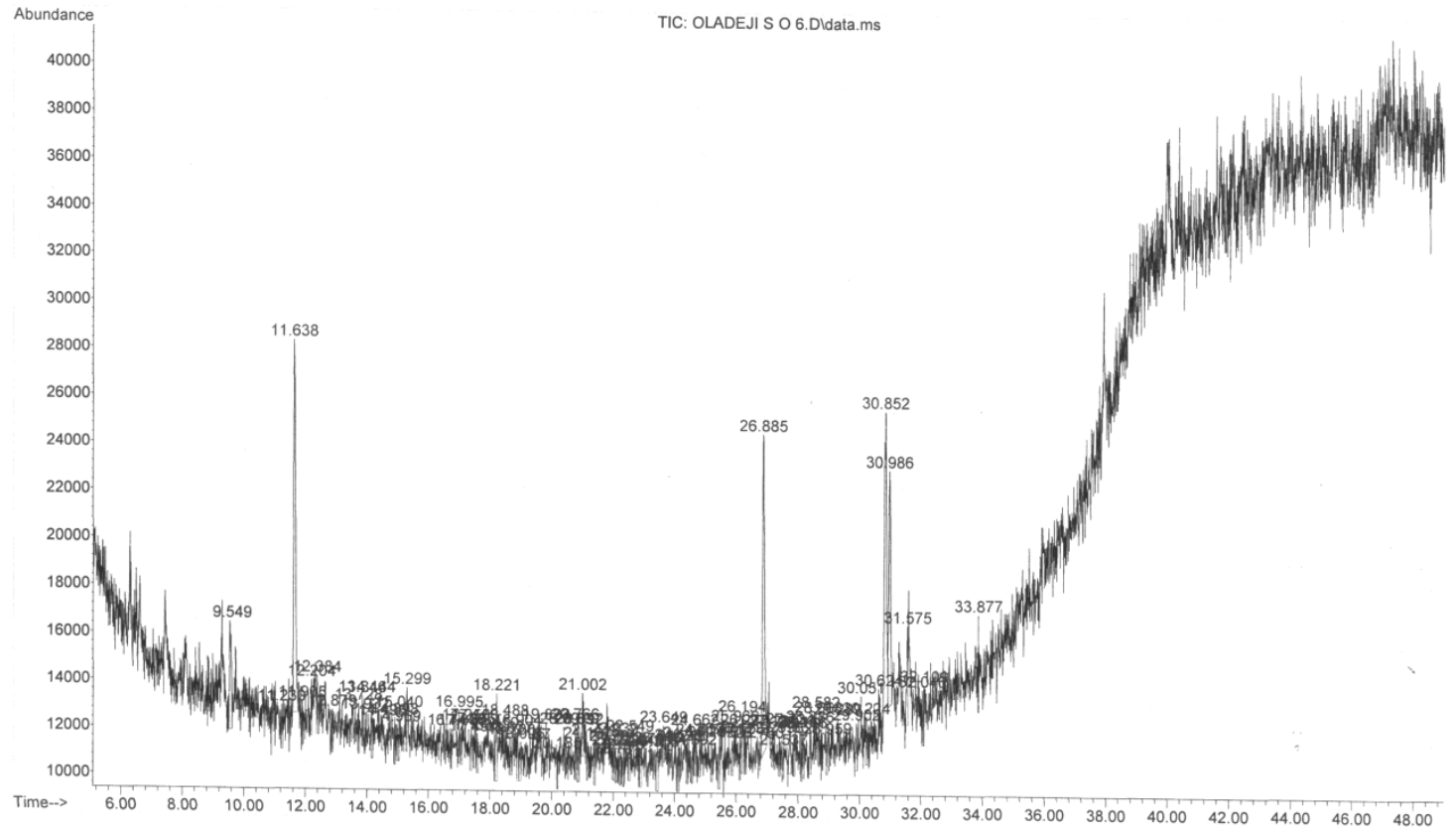

Figure 3. Gas chromatogram of Senna alata fruit.

Rev. Bras. Gest. Amb. Sustent., 2016, v. 3, n. 6, p. 355-365. 
From Tables 2, 3 and 4, the results obtained showed that the percentages of cinnamic acid present are of different quantities. It was also discovered that the flower extract contain the highest amount of cinnamic acid (52.91\%). The fruit contains the least amount of cinnamic acid $(17.03 \%)$. Cinnamic acids are a group of aromatic carboxylic acids $\left(\mathrm{C}_{6}-\mathrm{C}_{3}\right)$ appearing naturally in the plant kingdom (Xu et al., 2009). This agrees with the report of Wang et al. (2010); they discovered that the leaf of $S$. alata contain considerable amounts of (E)-cinnamaldehyde, a volatile aldehyde responsible for the pungent, sweet and hot flavour of $S$. alata. The high level of cinnamic acid and their derivatives in the flower extract indicated the several medicinal applications of $S$. alata flower. Also, the results agree with the report of Martin-Tanguy et al. (1978), in their findings, they discovered the presence of cinnamic amides in the reproductive organs of flowers of S. alata.

Table 3. Phenolic compounds identified from the GC analysis of the fraction eluted from leaf extract.

\begin{tabular}{llccc}
\hline $\begin{array}{l}\text { Chromatographic } \\
\text { peak }\end{array}$ & \multicolumn{1}{c}{ Compound name } & $\begin{array}{c}\text { Molecular } \\
\text { weight }\end{array}$ & $\begin{array}{c}\text { Retention } \\
\text { time }\end{array}$ & Peak area (\%) \\
\hline 1 & 3,5-Diethyl-2-n-propylpyridine & 177 & 11.646 & 18.04 \\
2 & Cinnamic acid & 250 & 20.507 & 46.37 \\
3 & Hexadecanoic acid & 256 & 26.885 & 16.06 \\
4 & Rhodopin & 536 & 30.976 & 19.524 \\
\hline
\end{tabular}

Table 4. Phenolic compounds identified from the GC analysis of the fraction eluted from flower extract.

\begin{tabular}{llccc}
\hline Chromatographic peak & Compound name & Molecular weight & Retention time & Peak area (\%) \\
\hline 1 & Cinnamic acid & 250 & 20.468 & 52.91 \\
2 & 2-Thiazolamine & 250 & 26.332 & 13.70 \\
3 & Hexadecanoic acid & 256 & 28.527 & 33.40 \\
\hline
\end{tabular}

In this study, the essential oil of the plant have been found to contained about $16.06 \%$ (leaf), $33.40 \%$ (flower) and $24.45 \%$ (fruit) of hexadecanoic acid and hence would be expected to exercise potent antibacterial, antifungal properties which would therefore be effective in the management of some bacterial and fungal infections. The result agrees with the report of Omotoyinbo et al. (2015). They reported that $S$. alata contain $n$-Hexadecanoic acid in methanolic extract of $S$. alata discovered that it contains $9.49 \%$. The result obtained from GC-MS analysis of methanolic extract by Sermakkani et al. (2009) indicated that $S$. alata contain unsaturated fatty acid with retention time and peak area of $16.48 \mathrm{~min}$ and $1.28 \%$ which is lower to the amount obtained from this research. This may be due to the extraction methods, location of the plants and most especially, the methods used for the analysis. Therefore, thin-layer and gas chromatographic analyses revealed the presence of different classes of phenolic compounds. From Table 1, gallic acid $\left(R_{f}=0.43\right)$ have a low retardation value to quercetin $\left(\mathrm{R}_{\mathrm{f}}=0.72\right)$. This showed that gallic acid is less polar to quercetin. The $R_{f}$ values of polar substances or compounds increases as the polarity of the substances decreases.

\section{Antimicrobial \\ activities: determination of Minimum Inhibitory Concentration (MIC)}

The ethanolic and methanolic of S. alata plant showed antibacterial and antifungal properties and all tested bacterial and fungal isolates responded positively to the extracts. The Minimum Inhibitory 
Concentrations (MIC) are shown in Table 5. There are tremendous microbial effects on A. niger (Figure 4) and C. albicans compared to the corresponding bacteria used. This agreed well with several reports in which similar observations were made (Sule et al., 2011). The result of this study revealed the effect of ethanol fractions on Candida albicans to be significantly higher than the methanol leaf which thus similar to report of Ogunti and Olujoba, (1993) where the ethanolic fraction was found to exhibit marked antimicrobial activity against $A$. niger and $C$. albicans when compared to methanolic fractions. The presence of these phenolic compounds has been found to be responsible for the fungicidal activity (Khan et al., 2001). Variations in the concentrations of the phenolic compounds in ethanolic and methanolic fractions are responsible for the differences in the fungicidal activity between the methanolic and ethanolic (Timothy et al., 2012). The Minimum Inhibitory Concentration obtained showed that $A$. niger and $C$. albicans are more susceptible to the ethanolic leaf even at low concentration when compared with $S$. aureus, B. cereus and Klebsiella spp. This study justifies the ethno medical use of this plant in the inhibition of bacterial and other fungal diseases. We believe that the results obtained from this study are an encouragement for further studies that will lead to the elucidation of the structure of the active components.

Table 5. Inhibitory effect of the fractions on the growth of fungi and bacteria species expressed through $\mathrm{MIC}$ in $\mu \mathrm{g} / \mathrm{mL}$.

\begin{tabular}{lcccccc}
\hline Test organisms/ fractions & ME flower & ME fruit & ME leaf & EE flower & EE fruit & EE leaf \\
\hline Staphylococcus aureus & 10 & 25 & 25 & 10 & 25 & 25 \\
Bacillus cereus & 10 & 25 & 25 & 10 & 25 & 25 \\
Klebsiella spp & 10 & 25 & 25 & 10 & 25 & 10 \\
Aspergillus niger & 5 & 10 & 10 & 10 & 10 & 5 \\
Candida albican & 5 & 10 & 10 & 5 & 10 & 10 \\
\hline
\end{tabular}

Where: $\mathrm{ME}=$ Methanolic, EE= Ethanolic.

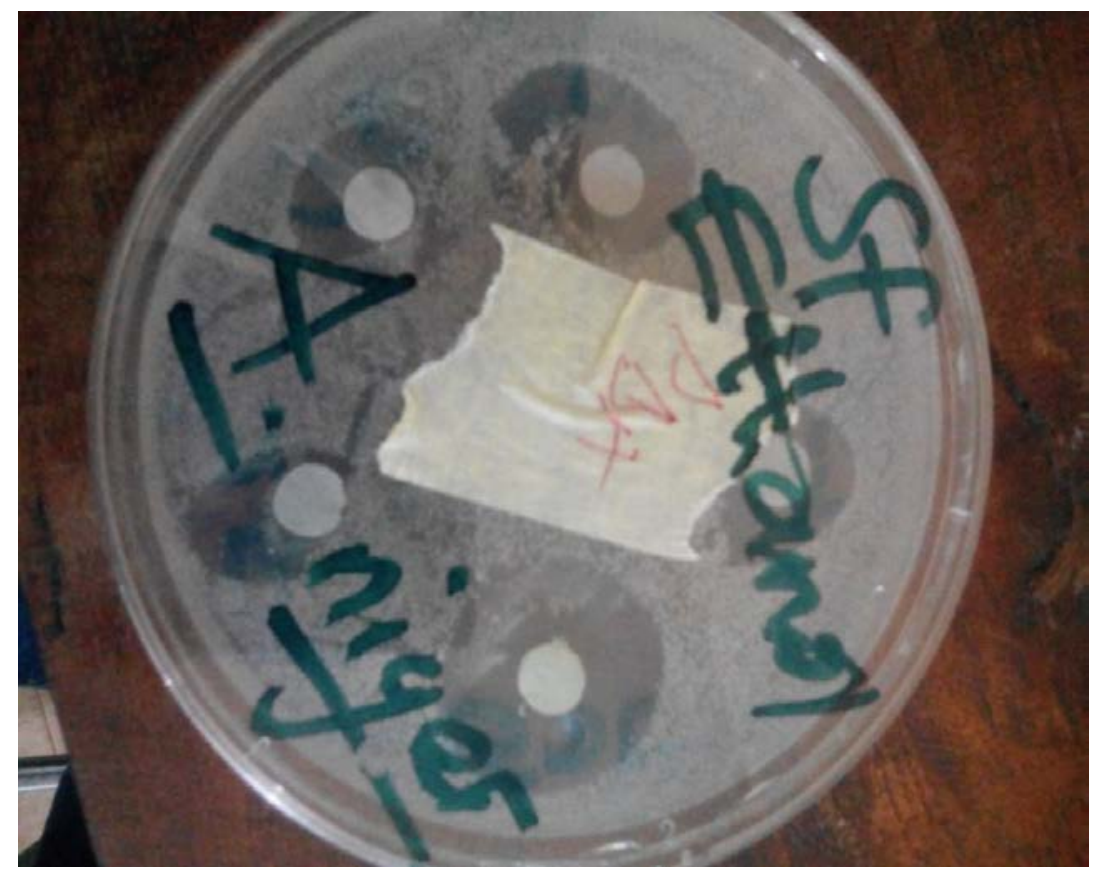

Figure 4. The zone of inhibition of ethanolic extract of Senna alata leaf against Aspergillus niger. 


\section{Conclusion}

The present study has clearly shown showed that Senna alata contain phenolic compounds and they dictate the antimicrobial properties of the plant. The observed antifungal and antibacterial activities on the susceptible organisms studied are due to the presence of phenolic compounds and thereby useful in pharmacy and phytotherapy, therefore, the phenolic compounds present in the plant dictate its microbial activities.

Contributions to knowledge:

(i) It enlightens on the great value of S. alata and also indicates that they are natural sources of antimicrobial substances of high importance.

(ii) The study justify the traditional believe of $S$. alata as antifungal and even enlighten about its antibacterial.

(iii) It shows that the therapeutic potency of this plant may be due to the presence of phenolic compounds.

(iv) It shows that $S$. alata may be useful for the preparation of bactericidal and fungicidal drugs.

\section{Conflict of interest statement}

Authors declare that they have no conflict of interests.

\section{Acknowledgement}

The authors thank Mr. Kehinde Odelade of the Department of Pure and Applied Biology, Lautech, Ogbomoso for his support and assistance with the antimicrobial screening.

\section{References}

Adelowo, $\quad$ F. E.; $\quad$ Oladeji, $\quad$ S. O. Spectrophotometric analysis of phenolic compounds in Senna alata. Am. J. Adv. Sci. Res., v. 3, p. 246-253, 2016.

Akinyemi, K.; Coker, A. O.; Bayaghon, C.; Oyefolu, A. O.; Akinside, K. A.; Omonigbeyin, E. O. Antibacterial screening of five Nigerian medicinal plants against S.typhi and S. paratyphi. J. Nig. Inf. Cont. Ass., 3-14, 2000.
Biesaga, M. Influence of extraction methods on stability of flavonoids. J. Chrom. Ana., 1218, p. 2505-2512, 2011.

Careri, M.; Mangia, A. Gas chromatographymass spectrometry analysis of flavor and fragrances. In: Niessen, W. M. A. (Ed.). Current practice in gas chromatographymass spectrometry. New York: Marcel Dekker, 2001.

Farnsworth, N.; Bunyapraphatsara, N. Thai medicinal plant: recommended for Primary Health Care System. Bangkok, Thailand: Prachachon Company, 1992.

Jennings, W.; Mittlefehldt, E.; Stremple, P. Analytical gas chromatography. 2. ed. Academic Press, 1997.

Kliebenstein, D. Secondary metabolites and plant/environmental interaction: a view through Arabidopsis thaliana tinged glass. P. Cell Env., v. 27, p. 675-684, 2004.

Makinde, A.; Igoli, J.; Amal, L.; Shaibu, S.; Garbal, A. Antimicrobial activity of Cassia alata. Afr. J. Biotechn., v. 6, p. 1509-1510, 2007.

McGorrin, R.. Food. In: Meyers, R. Encyclopedia of analytical chemistry applications: theory and instrumentation. New York: Wiley, 2000. p. 3857-4332.

Ogunti, E.; Olujoba, A. Laxative activity of Cassia alata. Fitoterapia Econ Bot., v. 64, p. 437-439, 1993.

Omotoyinbo, J. A.; Oladele, I. O.; Adewara, J. O. Investigating the effect of chemical treatment on the constituents and tensile properties of sisal fibre. J. Min. Mat. Char. Eng., v. 9, p. 569-582, 2010.

Osbourn, A.; Qi, X.; Townsend, B.; Qin, B. New phytology: overview of the therapeutic potential of piplartine (piperlongumine). Eur. J. Pharm. Sci., v. 48, p. 453-463, 2003.

Owoyale, J.; Olatunji, G.; Oguntoye, S. Antifungal and antibacterial activities of an ethanolic extract of Senna alata leaves. J. Appl. Sci. Environ. Manag., v. 9, p. 105-107, 2005.

Rahman, M.; Yasmin, T.; Shaheen, H. L.; Shaheen, T.; Tabassam, N.; Zafar, Y. Harvesting genetic diversity in the cotton genome. Proc. of National Symposium on Biotechnology for Economic Prosperity, National Commission on Biotechnology, Nathiagali, Pakistan, 2006.

Scott, R. Introduction to analytical gas chromatography. 2. ed. Marcel Dekker, 1998. 
Sermakkani, M.; Thangapandian, V. GC-MS analysis of Cassia italic leaf methanol extract. Asian J. Pharm. Clinical Res., v. 5, p. 90-94, 2012.

Shahidi, F.; Wanasundara, P. Phenolic Antioxidants. Crit. Rev. Food Sci. Nut., v. 32, p. 67-103, 2004.

Sule, W.; Okonko, I.; Joseph, T.; Ojezele, M.; Nwanze, J.; Alli, J.; Adewale, O.; Ojezele, O. In-vitro antifungal activity of Senna alata Linn. crude leaf extract. Adv. Appl. Sci. Res., v. 1, p. 14-26, 2010.

Timothy, S.; Lamu, F.; Rhoda, A.; Adati, R.; Maspalma, I.; Askira, M. Acute toxicity, phytochemistry and antibacterial activity of aqueous and ethanolic leaf extracts of Cassia alata Linn. Int. Res. J. Pharm., v. 3, p. 73-76, 2012.

Usha, V. Preliminary phytochemical evaluation of the leaf extract of five Cassia species. J. Chem. Pharm. Res., v. 3, p. 574-583, 2011.

Viera, R. F.; Skopura, L. A. Brazilian medicinal plants gene bank. Acta Horticul., v. 330, p. 51-58, 1993.

Wagner, U.; Edwards, R.; Dixon, D. P.; Mauch, F. Probing the diversity of the Arabidopsis glutathione S-transferase gene family. Plant Mol Biol., v. 49, n. 5, p. 515-532, 2002.

Whiting, D. Plants and their chemical composition. Nat. Prod. Rep., v. 18, p. 583, 2001.

Xu, B. J.; Chang, S. K. A comparative study on phenolic profiles and antioxidant activities of legumes as affected by extraction solvents. J. Food Sci., v. 72, p. 159-166, 2009. 